Niepełnosprawność. Dyskursy pedagogiki specjalnej

Nr 28/2017

Disability. Discourses of special education

No. $28 / 2017$

\title{
Sławomir Przybyliński
}

Uniwersytet Warmińsko-Mazurski w Olsztynie

Amadeusz Krause

Uniwersytet Gdański

\section{Zjawisko autoagresji w polskim systemie penitencjarnym}

Czyny autoagresywne więźniów, notowane w polskich zakładach karnych i aresztach śledczych, nie stanowią novum, a są zjawiskiem od lat notowanym w instytucjach penitencjarnych. Pomimo że ich liczba maleje i nie jest już tak spektakularna jak kiedyś, to nadal jednak atak na własne ciało stanowi wyzwanie dla pracy personelu więziennego, jak również dla holistycznie pojętego procesu resocjalizacji. Naszym zamiarem było, by w niniejszym artykule zarysować wątki powiązane i dookreślające to trudne zjawisko. Oprócz nakreślenia warstwy teoretycznej związanej w więzienną autoagresją, przybliżyliśmy także statystyczny obraz m.in. samoagresji w postaci usiłowań samobójczych i zgonów osadzonych w wyniku autoagresji, jak również ukazaliśmy przyczyny samoagresji osadzonych.

Słowa kluczowe: więzienie, czyny autoagresywne, proces resocjalizacji, osoby pozbawione wolności

\section{The phenomenon of self-aggression in the Polish penitentiary system}

Self-aggressive acts of prisoners have been observed in Polish penitentiary institutions and detention centers not only recently, but for years. Although their number is decreasing and is no longer as spectacular as it used to be, an attack on one's own body is still perceived as a challenge in the work of prison staff as well as in the holistically understood resocialization. The aim of this paper was to present the threads which relate to and describe this difficult phenomenon. In addition to showing a theoretical background referring to prison self-aggression, we also presented a statistical analysis of self-aggressive acts, including suicide attempts and deaths caused by selfaggressive, as well as the causes of self-aggression among prisoners.

Keywords: prison, self-aggressive acts, process of resocialisation, persons deprived of freedom 


\section{Wprowadzenia słów kilka}

Pozbawienie wolności jest najostrzejszą reakcją społeczną na przekroczenie granic prawnych, reakcją, która niesie ze sobą wielowymiarowe konsekwencje zogniskowane na osobie uwięzionej. E. Goffman [1975, s. 151-177] jednostki penitencjarne postrzega jako instytucje totalne, posiadające określone cechy totalności, które modelują poniekąd życie i determinują wiele poczynań pensjonariuszy placówki. Więzienie jako środowisko nienaturalne, a według H. Machela [2003] instytucja karna i resocjalizacyjna, stwarza skazanym takie, a nie inne, warunki codziennej egzystencji wielowymiarowo zubożonej. „Penitencjarne instytucje izolacyjne ograniczają w znacznym stopniu bądź całkowicie uniemożliwiają zaspokajanie fizycznych potrzeb człowieka, krępując w ten sposób funkcjonowanie jednostek poddanych krańcowej izolacji pejoratywnej" - powiada A. Bałandynowicz [2012, s. 15]. Zakładając maskę więźnia, wytrąconym ze środowiska otwartego, wkracza się na ścieżkę nijaką pod względem dotychczasowych składników funkcjonowania. Potrzeby pozostają, ale już bez większych możliwości ich urzeczywistnienia. Deprywacja potrzeb za murami więzienia staje się więc faktem niezbywalnym, z którym jednostka w różny sposób musi sobie radzić. Bywa, że pierwszoplanowe stają się wówczas nielegalne czy pozaformalne korelaty, czy zachowania osób osadzonych, umocowane w obrębie drugiego życia więziennego. Podkultura więzienna [zob. Przybyliński 2005], bez względu na jej terytorialny obraz i nasilenie, pozwala, a nieraz wprost dyktuje, swoim zwolennikom gotowe rozwiązania w zakresie zaspokajania potrzeb.

Być może trudno jest w obrębie podkulturowego towarzystwa wzmocnić zubożone przez izolację płaszczyzny sensoryczne, czy informacyjne $z$ otoczeniem zewnętrznym, lecz na pewno można tam doświadczyć z różnorakim natężeniem realizacji potrzeby bezpieczeństwa, przynależności, uznania. Osobno należałoby tu rozpatrywać potrzebę seksualną człowieka, której zaspokojenie w środowisku osób inkarcerowanych jest nie tyle trudne, co wręcz niemożliwe z punktu widzenia osób wolnych. Więziennictwo nie daje, oprócz jednostkowych w formie nagrody widzeń intymnych skazanych, sposobności na zapewnienie osiągnięcia satysfakcji seksualnej. To m.in. stymuluje poniekąd więźniów do wkraczania na nielegalną ścieżkę realizacji tej ważnej w życiu człowieka potrzeby. Notujemy więc nieraz wśród pensjonariuszy zakładu karnego gwałty homoseksualne, znęcanie się seksualne nad współosadzonym, czy też zabawy - gierki o podłożu erotycznym notowane w celi mieszkalnej. B. Waligóra [1984, s. 57-58] wskazuje pewien zestaw zaburzeń notowanych u człowieka przebywającego w warunkach izolacji eksperymentalnej. Wskazuje też na poczucie nudy i monotonii przechodzące później w apatię i zniechęcenie oraz niechęć do podejmowania wysiłku, 
trudności w koncentracji uwagi, zaburzenia funkcji intelektualnych oraz zakłócenia procesu myślenia, iluzje i zaburzenia schematu własnego ciała, silne lęki, halucynacje (najczęściej wzrokowe), wydarzenia urojeniowe, wyczerpanie fizyczne i psychiczne. Bezwzględnie niejednokrotnie niemożność zaspokajania, przez skazanych przebywających $\mathrm{w}$ warunkach izolacji penitencjarnej, wielu konstytutywnych potrzeb ludzkich implikuje sytuacje nadzwyczajne i niespotykane z takim natężeniem w codzienności wolnościowej.

\section{Więzienna fotografia zjawiska autoagresji}

Jednym ze spektakularnych zdarzeń notowanych od lat, z różnym nasileniem w środowisku osób uwięzionych, jest zamach ukierunkowany na własny organizm, czyli autoagresja. M. Kosewski niniejsze poczynania o walorach agresywnych skoncentrowanych na sobie samym nazywa zachowaniami samoagresywnymi. Samoagresję definiuje jako „zachowanie człowieka, którego bezpośrednim celem jest wyrządzenie krzywdy własnemu organizmowi. Istnienie takiego bezpośredniego celu działania jest warunkiem niezbędnym zaliczania takiego zachowania do kategorii zachowań samoagresywnych. Nie oznacza to, oczywiście, że poza takim bezpośrednim skutkiem nie mogą istnieć bardziej odległe, pośrednie cele lub motywy tego działania" [Kosewski 1977, s. 158]. Autor [1977, s. 159-172] wyszczególnia trzy kategorie zachowań samoagresywnych. Są to zachowanie samoagresywne, którego cel bezpośredni pokrywa się z celem pośrednim, a zasadniczym powodem postępowania jest wyrządzenie krzywdy samemu sobie przy czym, jak podaje Kosewski - przeważającą emocją w tym poczynaniu są lęk i niepokój. Do drugiej kategorii zalicza samoagresję agresywną, która występuje z chwilą, kiedy nie sposób wziąć odwetu na osobie frustrującej, inaczej niż szkodząc samemu sobie. Priorytetowy jest tu pośredni motyw agresywny z gniewem jako najsilniejszą emocją. Samoagresja instrumentalna, to kategoria trzecia, w której agresja skoncentrowana na własnym organizmie stanowi sposób zaspokojenia określonych potrzeb i osiągnięcia dowolnego celu, posiadając, w odróżnieniu od dwóch pierwszych kategorii o wektorze emocjonalnym, instrumentalne podłoże. M. Kosewski podaje dwa typy samoagresji emocjonalnej, wskazując na samoagresję gniewną oraz lękową. W pierwszym przypadku agresor sprawiając sobie ból i cierpienie ma na celu doprowadzenie do bezpośredniego odczucia ulgi i spadku natężenia odczuwanego gniewu. Natomiast typ drugi samoagresji tzw. emocjonalnej ma charakter lękowy (samoagresja lękowa). Osoba nie chce sprawić sobie bólu, chce jednak zniwelować występujący u siebie lęk i niepokój. Uważa, że może to osiągnąć przez działanie samoagresywne. 
G. Babiker i L. Arnold [2002, s. 177] wskazują na więzienia, szpitale specjalistyczne oraz inne placówki zamknięte jako miejsca, w których odnotowuje się największą liczbę przypadków samouszkodzeń. Więzienie, jak już wspomniano wyżej, sprzyja aktom agresji zogniskowanym na własnym ciele. Akty samouszkodzeniowe występują najczęściej w pierwszej fazie odbywania kary pozbawienia wolności, jak stwierdza J. Górski [1986, s. 43] po analizie wyników badań obejmujących 975 aktów samoagresywnych, które zostały dokonane przez więźniów w drugim i trzecim kwartale 1984 roku w 17 aresztach śledczych i 25 zakładach karnych w Polsce.

Od tamtego czasu minęło wiele lat i wizerunek zjawiska autoagresji zmienił się istotnie. Inne są warunki i zasady odbywania kary, co musi mieć bezpośrednie przełożenie na portret współczesnej autoagresji więźniów. Uwidacznia się to przede wszystkim w liczbowym zestawieniu. W polskich statystykach więziennych mówi się o zjawisku samoagresji, a w jego obrębie wyszczególnia, obok samouszkodzeń, także odmowę przyjmowania pokarmu oraz usiłowanie dokonania samobójstwa. Jak wynika z danych zawartych w tabeli 1 liczba samoagresji wśród osadzonych w polskich więzieniach na przestrzeni ostatnich lat uległa znacznemu zmniejszeniu, co niewątpliwie należy postrzegać pozytywnie. Mniej aktów skierowanych na własny organizm, to mniej sytuacji problemowych i poszerzona przestrzeń do pracy resocjalizacyjnej. Z tabeli 1 wynika wyraźnie, że w 2000 roku najczęściej notowanym wśród osadzonych rodzajem samoagresji były samouszkodzenia - 904, gdy w 2014 roku już tylko 36 takich czynów, a w 2015 roku takich czynów zanotowano 31. Dla porównania [Święconek 1986, s. 4-7] w roku 1985 tylko w samych jednostkach penitencjarnych okręgu olsztyńskiego zanotowano aż 338 samouszkodzeń (połyki - 166, okaleczenia ciała - 129, wbitki - 29, zatrucia - 8, wstrzyknięcia - 3, zasypki - 3, samopodpalenia-0).

Warto zauważyć, iż zgodnie z art. 119 kodeksu karnego wykonawczego ${ }^{1}$ osadzonego samouszkodzeniowca można w całości lub częściowo obciążyć odpłatnością za leczenie. Dotyczy to jednak tylko osób dokonujących samouszkodzeń o charakterze instrumentalnym, czyli takich, którzy atakują samych siebie w celu wymuszenia określonej decyzji lub postępowania organu wykonawczego, lub uchylenia się od ciążącego na nim obowiązku. O ewentualnym obciążeniu finansowym skazanego decyduje sąd penitencjarny. „Wprawdzie tylko niektóre koszty zabiegów medycznych przekraczają kwoty kilku tysięcy złotych, a zdecydowana większość zamyka się w kilkusetzłotowych sumach, to są one trudne do odzyskania. Rzadko kiedy samouszkodzeniowiec trafia do odpłatnej pracy. Częściej udaje mu się opuścić jednostkę z powodu warunkowego zwolnienia (...)" [Jarecka 2008, s. 27]. Warto zauważyć, iż obciążenie skazanego kosztami leczenia pobiera się

Ustawa z dnia 6 czerwca 1997 r. - Kodeks karny wykonawczy (Dz. U. Nr 90, poz. 557 ze zm.), art. 119 $\S 1,2$. 
z jego zarobków lub też ich każdych innych wpływów, np. środki przekazywane przez rodzinę czy z renty. Jeżeli jednak brakuje jakichkolwiek wpływów pieniężnych, płatności się umarza [Łupińska 2010, s. 18-19]. Nie sposób wyceniać całkowitych kosztów leczenia więźnia po dokonaniu samouszkodzenia. Dyrektor Zakładu Opieki Zdrowotnej w Areszcie Śledczym na warszawskim Mokotowie - Lech Malmurowicz wspomina: „Skazany włożył sobie do gałki ocznej baterię od zegarka. Łzy rozpuściły baterię, rozlany płyn zasadowy zniszczył całą rogówkę. Potrzebny był przeszczep, a koszty takiej operacji bardzo duże. Podobne sumy wydaje się na leczenie antyretrowirusowe, bo niektórzy więźniowie z premedytacją zarażają się wirusem HIV, wstrzykując go sobie dożylnie" [Łupińska 2010, s. 19].

Tabela 1. Samoagresje w latach $2000-2015^{2}$

\begin{tabular}{|c|c|c|c|c|}
\hline Rok & Ogółem & $\begin{array}{c}\text { Odmowa przyjmo- } \\
\text { wania pokarmu }\end{array}$ & Samouszkodzenia ${ }^{3}$ & $\begin{array}{l}\text { Usiłowanie } \\
\text { samobójstwa }\end{array}$ \\
\hline 2000 & 1134 & 39 & 904 & 191 \\
\hline 2001 & 1130 & 51 & 889 & 190 \\
\hline 2002 & 948 & 43 & 733 & 172 \\
\hline 2003 & 664 & 27 & 507 & 130 \\
\hline 2004 & 730 & 23 & 572 & 135 \\
\hline 2005 & 773 & 16 & 570 & 187 \\
\hline 2006 & 795 & 20 & 587 & 188 \\
\hline 2007 & 633 & 10 & 449 & 174 \\
\hline 2008 & 715 & 27 & 497 & 191 \\
\hline 2009 & 818 & 15 & 592 & 211 \\
\hline 2010 & 622 & 25 & 450 & 147 \\
\hline 2011 & 433 & 37 & 205 & 191 \\
\hline 2012 & 281 & 35 & 96 & 150 \\
\hline 2013 & 266 & 27 & 51 & 188 \\
\hline 2014 & 217 & 6 & 36 & 175 \\
\hline 2015 & 215 & 11 & 31 & 173 \\
\hline
\end{tabular}

Źródło: Opracowanie własne.

2 Zestawienie dokonane przez autora na podstawie Informacji o wykonywaniu kary pozbawienia wolności i tymczasowego aresztowania za lata 2000-2008 oraz Roczne informacje statystyczne za lata 2009-2015 Ministerstwo Sprawiedliwości, Centralny Zarząd Służby Więziennej, Warszawa.

3 Uwzględniono przypadki, w których przewidywany czas rozstroju zdrowia był nie krótszy niż 7 dni. 
Istotnym czynem samoagresywnym dokonywanym przez więźniów są samouszkodzenia. Zarówno praktyka penitencjarna, jak i literatura przedmiotu dostarczają szeroką wiedzę na temat ich rodzajów, a nieraz także więzienną pomysłowość w tym zakresie. M. Szaszkiewicz [1997, s. 105-116] podaje, iż w środowisku inkarcerowanym notowane są w szczególności pocięcia skóry, połknięcie ciał obcych, wbitki, czyli wprowadzanie ciał obcych pod skórę i do narządów ciała, uszkodzenie gałek ocznych, samozatrucia, upusty krwi, Ustrzyki, czyli samozakażenie, głodówki, urazy głowy. Natomiast L. Garmada [1970, s. 17-58], pracując ponad 15 lat jako lekarz więzienny i obserwując ponad tysiąc przypadków samouszkodzeń, wyszczególnia następujące rodzaje: głodzenie się i głodówki, krwioupusty i pozorowane krwotoki, nacięcia skóry i tkanki podskórnej, w tym pocięcia powłok brzusznych, zakażenia tkanki podskórnej, zatrucia doustne, chemiczne i mechaniczne uszkodzenia gałki ocznej, wprowadzanie ciał obcych do przewodu pokarmowego, wprowadzanie ciał obcych pod skórę i przez powłoki do narządów głębszych, wchłanianie ciał obcych do drzewa oskrzelowego, urazy czaszki bezpośrednie i za pomocą ciał obcych, uszkodzenia innych narządów.

Pomysłowość osób uwięzionych w zakresie samouszkodzeń jest znaczna, więc nie sposób wymienić wszystkich ich rodzajów. Zdarzają się incydentalnie spotykane czyny, tj. urazy głowy lub innych części ciała (np. łamanie sobie palców, rąk). Jedno jest pewne, że najbardziej doniosłą i spektakularną postacią samoagresji więźniów są próby samobójcze, nieraz kończące się śmiercią samobójcy. Są to czyny wielce tragiczne i posiadające niejednolite podłoże przyczynowe. $Z$ danych więziennych wynika, że usiłowania samobójcze, kończące się śmiercią, nie są jednostkowymi sytuacjami. W 2015 roku 20 osadzonych zmarło śmiercią samobójczą, a w latach 2010-2015 było ich aż 122 (tab. 2). Zdecydowana większość samobójstw więźniów dokonywana jest przez powieszenie. Potwierdzają to także T. Głowik i A. Matyba [2010, s. 15-17], którzy analizując 155 samobójstw skazanych i tymczasowo aresztowanych mających miejsce $w$ realiach polskiego więzienia w latach 2006-2009, wskazali, iż aż 143 z nich zostało popełnionych właśnie przez powieszenie. Autorzy podają także, że najczęstszym miejscem tego tragicznego aktu jest cela mieszkalna. W latach 2006-2008 ok. 25\% wszystkich samobójstw miało miejsce w kąciku sanitarnym, a blisko 60\% w innej części celi (krata okienna, albo piętrowe łóżko). Natomiast w roku 2009 w kąciku sanitarnym dokonano aż 45\% aktów samobójczych, przy 49\% samobójstw w innej części celi mieszkalnej.

Zarówno samobójstw, jak i pozostałych czynów samoagresji więźniów nie można i nie należy pod względem przyczyn sprowadzić do jednego mianownika. L. Garmada [1970, s. 11-16], odnosząc się już wiele lat temu do kwestii samouszkodzeń, za ich podłoże przyjął zespół specyficznych objawów psychicznych ujawniających się w sytuacji odizolowania, a zwanych chorobą więzienną. Objawami 
tej przewlekłej choroby są: zachwianie równowagi duchowej, poddanie się nudzie więziennej, egocentryzm i zmienność nastrojów. Gwałtowne czyny służące wyładowaniu napięcia nerwowego i tłumionej agresji mają pojawiać się więc w chwilach kryzysowych. Chorobę więzienną charakterystycznie przechodzą jednostki, które w swoim życiu kierują się agresją, a miano takich noszą przestępcy kryminalni. Życie ich to pasmo agresji skierowanej wobec cudzego mienia, zdrowia, życia. Szybko jednak takie zachowanie zostaje poddane represji ze strony współosadzonych i personelu. Dla takiego skazanego pozostaje tylko jedno wyjście, gdzie można stosować przemoc bezkarnie: to jego własne ciało.

Tabela 2. Samoagresje - usiłowania samobójcze i zgony osadzonych w wyniku autoagresji w latach 2010 - 2015

\begin{tabular}{|c|c|c|c|c|}
\hline Rok & $\begin{array}{c}\text { Ewidencyjna } \\
\text { liczba osadzonych } \\
\text { według stanu } \\
\text { w dniu 31 grudnia }\end{array}$ & $\begin{array}{c}\text { Usiłowania } \\
\text { samobójcze }\end{array}$ & $\begin{array}{c}\text { Zgony w wyniku } \\
\text { autoagresji } \\
\text { (samobójstwo oraz } \\
\text { samouszkodzenia) }\end{array}$ & $\begin{array}{c}\text { W tym w wyniku } \\
\text { samobójstwa }\end{array}$ \\
\hline 2010 & 85295 & 147 & 34 & 31 \\
\hline 2011 & 81382 & 191 & 22 & 16 \\
\hline 2012 & 84156 & 150 & 18 & 16 \\
\hline 2013 & 78994 & 188 & 19 & 17 \\
\hline 2014 & 77371 & 175 & 26 & 22 \\
\hline 2015 & 70836 & 173 & 23 & 20 \\
\hline
\end{tabular}

Źródło: Opracowanie własne.

Z danych CZSW w Warszawie wynika, iż to działalność administracji jest najczęstszym rozpoznanym powodem samoagresji osób uwięzionych. Znaczna część przyczyn aktów samoagresji nie jest do końca znana i zdiagnozowana, jak wynika w danych więziennictwa (tab. 3), i umieszczane są pod hasłem "inne”. Można tylko domniemywać, iż wśród nich znajdują się właśnie sytuacje związane z silnymi emocjami człowieka pozbawionego wolności, a związane z tym co dzieje się na wolności, m.in. z sytuacją rodzinną osadzonego. Być może też część samookaleczeń jest sprowokowana przez podkulturowe zależności i nieformalny system zasad. Wszak statystyki więzienne uwzględniają jako powód samoagresji więźniów „presję podkultury więziennej” oraz „uczestnictwo w podkulturze więziennej". To jednak wydaje się, znając i obserwując środowisko podkulturowe współczesnego więzienia, że nie zawsze samouszkodzeniowcy mogą podać prawdziwy powód targnięcia się na własny organizm.

4 Dane Centralnego Zarządu Służby Więziennej, Biuro Informacji i Statystyki (przesłane mailowo w dniu 1 lutego 2016 r., BIS-0340-20/16/647). 
Tabela 3. Przyczyny samoagresji osadzonych w latach $2000-2015^{5}$

\begin{tabular}{|c|c|c|c|c|c|c|}
\hline \multirow[b]{2}{*}{ Rok } & \multirow[b]{2}{*}{ Ogółem } & \multicolumn{5}{|c|}{ Samoagresja z powodu... } \\
\hline & & $\begin{array}{c}\text { działalności } \\
\text { administracji }\end{array}$ & $\begin{array}{c}\text { presji } \\
\text { podkultury } \\
\text { więziennej }\end{array}$ & $\begin{array}{c}\text { uczestnictwa } \\
\text { w podkulturze } \\
\text { więziennej }\end{array}$ & $\begin{array}{l}\text { działalności } \\
\text { sądów } \\
\text { i prokuratury }\end{array}$ & inne \\
\hline 2000 & 1134 & 393 & 21 & 25 & 204 & 491 \\
\hline 2001 & 1130 & 359 & 20 & 35 & 223 & 493 \\
\hline 2002 & 948 & 308 & 23 & 44 & 119 & 454 \\
\hline 2003 & 664 & 198 & 8 & 24 & 83 & 351 \\
\hline 2004 & 730 & 255 & 4 & 13 & 65 & 393 \\
\hline 2005 & 773 & 217 & 4 & 22 & 81 & 449 \\
\hline 2006 & 795 & 273 & 9 & 18 & 69 & 426 \\
\hline 2007 & 633 & 199 & 9 & 10 & 65 & 350 \\
\hline 2008 & 715 & 234 & 7 & 7 & 68 & 399 \\
\hline 2009 & 818 & 325 & 2 & 5 & 60 & 426 \\
\hline 2010 & 622 & 266 & 1 & 9 & 35 & 311 \\
\hline 2011 & 433 & 139 & 1 & 3 & 41 & 249 \\
\hline 2012 & 281 & 97 & 2 & 1 & 20 & 161 \\
\hline 2013 & 266 & 60 & 0 & 1 & 13 & 192 \\
\hline 2014 & 217 & 48 & 1 & 0 & 13 & 155 \\
\hline 2015 & 215 & 43 & 0 & 1 & 7 & 164 \\
\hline
\end{tabular}

Źródło: Opracowanie własne.

„Motywami samouszkodzeń są najczęściej: wywarcie presji i odpowiedniego wrażenia na sędziach i prokuratorach, wymuszenie określonych ustępstw ze strony personelu więziennego, protest przeciwko decyzjom władz, załamanie psychiczne, na które wpływały wydarzenia rodzinne i osobiste. Tło zachowań suicydalnych $\mathrm{w}$ przypadku osób odbywających karę pozbawienia wolności może stanowić: po pierwsze - rzeczywistość więzienna, na którą składają się takie czynniki, jak: fakt uwięzienia, który jest zdarzeniem przymusowym, a jednocześnie odczuwanym jako upokarzające doznanie skutków przemocy społecznej. Po drugie, poddanie się wymogom - regulaminów, porządkowi i obowiązującemu podporządkowania się funkcjonariuszom, co powoduje uczucie bezsilności i upokorzenia. Po trzecie -monotonia i nuda, a przede wszystkim „deprywacja sensoryczna", wyzwalająca przykre uczucie braku zaspokajania własnych potrzeb, doznania wrażeń i zdobywania doświadczeń i po czwarte, brak poczucia

5 Zestawienie dokonane przez autora na podstawie Informacji o wykonywaniu kary pozbawienia wolności i tymczasowego aresztowania za lata 2000-2008 oraz Roczne informacje statystyczne za lata 2009-2015 Ministerstwo Sprawiedliwości, Centralny Zarząd Służby Więziennej, Warszawa. 
własnej odrębności i prywatności z całym bagażem nawet tych najintymniejszych spraw. Współcześnie nie bez znaczenia pozostaje również czynnik związany z tzw. zagęszczeniem w celach mieszkalnych" [Przybyliński, Marczak 2008, s. 447].

Generalizując, to przyczyny czy też motywy samouszkodzeń wśród więźniów możemy podzielić na tzw. emocjonalne i instrumentalne. Te pierwsze mogą i powinny skutkować zminimalizowaniem natężenia emocjonalnego oraz zniwelowaniem istniejących dolegliwości oraz obniżeniem poziomu frustracji, przygnębienia i zniechęcenia. Są one powiązane z tym, co dzieje się w przestrzeni otwartej, na którą więzień ma mocno ograniczony wpływ (m.in. nieprawidłowe stosunki interpersonalne z partnerem życiowym, choroba lub śmierć kogoś bliskiego itd.). Instrumentalne przyczyny zaś najczęściej powiązane są z pragnieniem uzyskania przez więźniów określonych korzyści, zysków czy też załatwienia partykularnych interesów. Chodzi tu w szczególności o chęć otrzymania przepustki, widzenia, przerwy w karze, ale również wymuszenie przeniesienia do innej celi mieszkalnej czy innego więzienia. Więźniowie z premedytacją i namysłem próbują poprzez atak na własne ciało, wyegzekwować na personelu służby więziennej korzystne dla nich decyzje i rozstrzygnięcia.

Pewna część aktów autoagresji kończy się zgonem osadzonego. W roku 2015 były to 23 osoby, przy 105 zgonach osadzonych w ogóle. Ilustruje to tabela 4 , w której widzimy, iż atak na własny organizm (w tym śmierć samobójcza) stanowi poważny udział w kompozycji śmierci wśród pensjonariuszy jednostek penitencjarnych. Ich odsetek kształtujący się na znacznym poziomie musi i powinien zastanawiać. Samobójstwa w zakładach karnych - jak twierdzi M. Jarosz - „są przejawem dramatycznego protestu przeciwko systemowi karnemu, warunkom odbywania kary, klimatowi i relacjom między personelem a więźniami oraz między samymi więźniami. Zachowania autoagresywne wskazują także na dysfunkcjonalność instytucji penitencjarnych - w sferze resocjalizacji oraz zapewnienia bezpieczeństwa osobistego ludzi pozbawionych wolności (agresji i autoagresja)" [Jarosz 1997, s. 170]. Wydaje się, że przy ogromnej grupie osób inkarcerowanych w Polsce - ponad 70 tys. - to liczba samych prób samobójczych, których i tak tylko część kończy się zgonem oraz śmiercią samobójczą, wydaje się niewielka. Jednak należy zauważyć, iż więzienie to instytucja, którą powołano w określonym celu, by odbywać w niej karę pozbawienia wolności czy tymczasowego aresztowania, a nie dotknąć śmierci tchnienia w sposób samobójczy, czy też istotnie uszkadzając własne ciało przez samouszkodzenie. Niemniej jednak zdarza się, że kres życia $\mathrm{z}$ różnych przyczyn ma miejsce również w przestrzeni izolowanej. Może się też dokonać z przyczyn naturalnych, w tym chorobowych. 
Tabela 4. Zgony osadzonych w latach 2002-2015

\begin{tabular}{|c|c|c|c|c|c|}
\hline \multirow{2}{*}{ Rok } & Ogółem & $\begin{array}{c}\text { w tym w zakładzie } \\
\text { leczniczym poza } \\
\text { aresztem śledczym } \\
\text { lub zakładem } \\
\text { karnym }\end{array}$ & $\begin{array}{c}\text { przyczyna } \\
\text { naturalna }\end{array}$ & $\begin{array}{c}\text { z powodu } \\
\text { autoagresji }\end{array}$ & inne \\
\hline 2002 & 96 & 17 & 56 & 40 & 0 \\
\hline 2003 & 127 & 29 & 86 & 37 & 4 \\
\hline 2004 & 107 & 19 & 67 & 30 & 10 \\
\hline 2005 & 122 & 22 & 84 & 32 & 6 \\
\hline 2006 & 154 & 21 & 112 & 42 & 0 \\
\hline 2007 & 145 & 36 & 95 & 41 & 9 \\
\hline 2008 & 135 & 21 & 93 & 39 & 0 \\
\hline 2009 & 125 & 27 & 84 & 41 & 10 \\
\hline 2010 & 135 & 32 & 91 & 34 & 3 \\
\hline 2011 & 127 & 30 & 102 & 22 & 0 \\
\hline 2012 & 107 & 28 & 89 & 18 & 3 \\
\hline 2013 & 109 & 36 & 80 & 19 & 26 \\
\hline 2014 & 107 & 27 & 75 & 23 & 0 \\
\hline 2015 & 105 & 28 & 79 & & 0 \\
\hline
\end{tabular}

Źródło: Opracowanie własne.

„Śmierć jest jednym z elementów ludzkiego istnienia na Ziemi. Nastąpi na pewno. I choćby człowiek czynił wielkie starania, nie jest w stanie jej zapobiec, a tylko w niektórych przypadkach może jedynie odroczyć moment jej nadejścia. Nie udało się bowiem, jak dotąd i zapewne nie uda się, stworzyć recepty na nieśmiertelność" [Antoszewska, Przybyliński 2012, s. 91]. Nieśmiertelny w sensie fizycznym nie jest człowiek i nieśmiertelne nie są też jego czyny. Choć w izolacji są to akty nieraz spektakularne, podszyte emocjami, cierpieniem, zwątpieniem czy beznadziejnością, gdzie jedynym wówczas jawiącym się kierunkiem działań jest unicestwienie samego siebie.

6 Zestawienie dokonane przez autora na podstawie Informacji o wykonywaniu kary pozbawienia wolności i tymczasowego aresztowania za lata 2002, 2003, 2004, 2005,2006, 2007, 2008 oraz Roczne informacje statystyczne za lata 2009, 2010, 2011, 2012, 2013, 2014, 2015 Ministerstwo Sprawiedliwości, Centralny Zarząd Służby Więziennej, Warszawa. 


\section{Zamiast zakończenia...}

Zachowania samoniszczące $w$ grupie osób osadzonych wpisały się już dawno w realia instytucji penitencjarnej. Mają tam swoje miejsce również we współczesnym więzieniu, niezmiennie stanowiąc poważny problem $\mathrm{w}$ procesie resocjalizacji skazanych. Bez względu na rodzaj dokonanego aktu autoagresji zawsze niosą one ze sobą prawdopodobieństwo finału ziemskiej egzystencji. Otóż w każdym takim czynie czuć śmierci tchnienie lub perspektywę różnorodnych reperkusji i powikłań zdrowotnych. Jakie jest zatem tło na poziomie myśli w początkowej fazie, a następnie aktu wycelowanego na zadanie sobie bólu? Otóż sam fakt uwięzienia czy też zawężenia przestrzeni życiowej implikuje, determinuje, a czasami $\mathrm{i}$ istotnie potęguje myśli o swoistym samounicestwieniu. Zatem pozbawienie człowieka egzystencji w przestrzeni otwartej jest pierwszoplanowym i priorytetowym powodem zjawiska autoagresji. Większość innych powodów może jedynie być tego pochodną, stając się logiczną konsekwencją pobytu w jednostce penitencjarnej. M. Jarosz [1997, s. 180] pisze, że bez względu na miejsce (środowisko otwarte czy zamknięte), to życie odbierają sobie „ludzie mniej odporni, uwikłani w sytuacje, które rzeczywiście (bądź we własnym mniemaniu) ich przerastają. Nie są w stanie rozwiązać węzła gordyjskiego, w który zapętliła się ich teraźniejszość. Przecinają go - kładąc kres życiu". Ta tragiczna finalnie chwila dzieje się i dziać się może bez względu na czas i miejsce. Śmierć samobójcza w przestrzeni współczesnego więzieniu nabiera jednak trochę odmiennego znaczenia niż na wolności, bo jakże inne warunki funkcjonowania towarzyszą człowiekowi w tych dwóch różnych światach.

\section{Bibliografia}

Antoszewska B., Przybyliński S. (2012), Śmierć i umieranie w umystach osób pozbawionych wolności, „Niepełnosprawność” - „Problemy esocjalizacji penitencjarnej i niedostosowania społecznego", nr 8.

Aries P. (1992), Człowiek i śmierć, przekł. E. Bąkowska, Warszawa.

Babiker G., Arnold L. (2002), "Autodestrukcja” - mowa zranionego ciała, Gdańsk.

Bałandynowicz A. (2012), Pejoratywne aspekty systemu izolacyjno-dyscyplinarnego [w:] Izolacja penitencjarna z perspektywy pejoratywnej i melioratywnej, M. Snopek (red.), Toruń.

Bourdieu P. (2004), Męska dominacja, przeł. L. Kopciewicz, Warszawa.

Ciosek M. (1996), Człowiek w obliczu izolacji więziennej, Gdańsk.

Garmada L. (1070), Samouszkodzenia ciata, Warszawa.

Geraga M. (2013), Imiona śmierci, „Przegląd humanistyczny. Pedagogika, politologia, filozofia", $\mathrm{nr}$ 7, Szczecin.

Głowik T., Matyrba A. (2010), Samobójstwa osadzonych w latach 2006-2009, „Przegląd Więziennictwa Polskiego", nr 66, Warszawa. 
Goffman E. (1975), Charakterystyka instytucji totalnych [w:] Elementy teorii socjologicznych: materiały do dziejów wspótczesnej socjologii zachodniej, wybór, W. Derczyński, A. Jasińska-Kania, J. Szacki (red.), Warszawa.

Górski J. (1986), Samouszkodzenia w zakładach karnych i aresztach śledczych, „Przegląd Penitencjarny i Kryminologiczny", nr 9-10, Warszawa.

Informacje o wykonywaniu kary pozbawienia wolności i tymczasowego aresztowania za lata 2000-2008 oraz Roczne informacje statystyczne za lata 2009-2015, Ministerstwo Sprawiedliwości, Centralny Zarząd Służby Więziennej, Warszawa.

Jarecka E., Kościelski K. (2008), Kosztowne chlastanie, „Forum Penitencjarne”, nr 2.

Jarosz M. (1997), Samobójstwa, Warszawa.

Kosewski M. (1977), Agresywni przestępcy, Warszawa.

Krause A., Przybyliński S. (red.) (2012), Resocjalizacja penitencjarna - aktualne wyzwania i rozwiązania, Kraków.

Łupińska A. (2010), Ile za połyk? Koszty leczenia samouszkodzeń, „Forum Penitencjarne”, nr 11.

Machel H. (2003), Więzienie jako instytucja karna i resocjalizacyjna, Gdańsk.

Waligóra B. (1984), Deprywacja potrzeb u osób pozbawionych wolności [w:] Problemy wspótczesnej penitencjarystyki w Polsce, B. Hołysz, Warszawa.

Przybyliński S. (2005), Podkultura więzienna - wielowymiarowość rzeczywistości penitencjarnej, Kraków.

Przybyliński S., Marczak M. (2008), Samouszkodzenia wśród osadzonych kobiet i mężczyzn [w:] Misja Stużby Więziennej a jej zadania wobec aktualnej polityki karnej i oczekiwań spotecznych, W. Ambrozik, H. Machel, P. Stępniak (red.), Poznań-Gdańsk-Warszawa-Kalisz.

Przybyliński S. (2016), Osobliwy obraz podkultury [w:] Psychologia penitencjarna, Ciosek M., Pastwa-Wojciechowska B. (red.), Warszawa.

Pytka L. (2011), Śmierć jako ambiwalencja, wykluczenie i nadzieja..., „Resocjalizacja Polska”, nr 2.

Szaszkiewicz M. (1997), Tajemnice grypserki, Kraków.

Szlęzak-Kawa E. (2012), Funkcjonariusz potrzebuje wsparcia, „Forum Penitencjarne”, nr 1.

Szlęzak-Kawa E. (2012), Na szali życia, „Forum Penitencjarne”, nr 1.

Święconek J. (1986), Problematyka samoagresji osadzonych w jednostkach okręgu olsztyńskiego. Wpływ podkultury więziennej na samoagresję, Olsztyn.

Ustawa z dnia 6 czerwca 1997 r. - Kodeks karny wykonawczy (Dz. U. Nr 90, poz. 557 ze zm.). 